Jurnal Akuntansi \& Manajemen

Vol.11, No.1, 2016

\title{
Pengelolaan dan Penyusunan Laporan Keuangan Desa/Nagari
}

\author{
Sukartini1 ${ }^{1}$, Amy Fontanella ${ }^{2}$ Novrina Chandra ${ }^{3}$ \\ ${ }^{1}$ Jurusan Akuntansi Politeknik Negeri Padang \\ tiensukartini28@gmail.com \\ 2Jurusan Akuntansi Politeknik Negeri Padang \\ amyfontanella99@gmail.com \\ 3Jurusan Akuntansi Politeknik Negeri Padang \\ novrina.chandra@gmail.com
}

\begin{abstract}
Abstrak
Pemerintah desa/nagari mendapat kucuran dana dari pemerintah pusat dalam jumlah yang tidak sedikit. Namun perangkat nagari belum memiliki kompetensi yang memadai dalam mengelola, menatausahakan dan mengelola keuangan nagari. Pengelolaan keuangan memerlukan akuntabilitas dan transparansi kepada public karena dana yang digunakan bersumber dari dana publik. UU No.6 tahun 2015 menjelaskan bahwa pemerintah desa mulai dari tahun 2015 akan memperoleh dana 10\% dari total anggaran. Oleh karena itu diperlukan kompetensi yang memadai dari perangkat desa dalam mengelola dan menyusun laporan keuangan untuk mewujudkan transparansi dan akuntabilitas pengelolaan keuangan. Untuk memudahkan perangkat nagari dalam menyusun laporan keuangan, penelitian ini mengembangkan aplikasi sederhana dalam penyusunan laporan keuangan nagari dengan basis Microsoft excel. Penggunaan aplikasi sederhana ini juga dapat meminimalkan kemungkinan terjadinya kesalahan dalam penyusunan laporan keuangan seperti kesalahan dalam perhitungan yang selama ini dilakukan melalui proses manual. Hasil penelitian ini menunjukkan berdasarkan proses pendampingan dalam menggunakan aplikasi, perangkat pengelola keuangan nagari merasa terbantu dalam melakukan pekerjaannya.
\end{abstract}

Kata Kunci : dana desa, laporan keuangan desa, pengelolaan keuangan. 


\section{PENDAHULUAN}

Pembangunan di desa/nagari saat ini sumber dananya tidak saja berasal dari Anggaran Pendapatan dan Belanja Desa (APBDesa) tetapi juga bersumber dari Anggaran Pendapatan dan Belanja Negara (APBN), Anggaran Pendapatan dan Belanja Daerah Propinsi (APBD Propinsi) maupun dari bantuan luar negeri yang mengharuskan perangkat desa/nagari mempunyai pengetahuan yang memadai mengenai penatausahaan pengelolaan keuangan.

Pemerintah desa/nagari adalah institusi yang setara dalam strata pemerintahan. Desa/nagari dikepalai oleh masyarakat sipil biasa yang dipilih melalui pemilihan langsung oleh masyarakatnya. Desa/nagari merupakan sebuah institusi legal formal dalam pemerintahan nasional. Hal itu tergambar dengan adanya kewenangan penuh bagi desa/nagari untuk menyelenggarakan pengelolaan keuangan sendiri. Kewenangan tersebut telah diatur oleh negara yaitu dalam UU No. 5 tahun 1979 tentang pemerintahan desa dan UU No. 32 Tahun 2004 tentang pemerintahan daerah, dijelaskan bahwa Desa/Nagari merupakan kesatuan masyarakat hukum yang berwenang untuk mengurus kepentingan masyarakatnya sendiri.

Hal ini dipertegas dengan adanya keharusan untuk menyusun APBDesa yang dijelaskan dalam Peraturan Menteri Dalam Negeri (Permendagri) No. 37 Tahun 2007 tentang Pedoman Pengelolaan Keuangan Desa. Dengan adanya kewenangan pengelolaan keuangan tersebut, maka secara hukum pemerintah desa/nagari wajib untuk melaporkan kinerjanya kepada pemerintah dan masyarakat.

\section{Kondisi Mitra}

Mitra terdiri dari 2 desa/nagari yaitu Nagari Garaghan dan Nagari Lubuk Basung. Kedua mitra ini lokasinya sama yaitu di lokasi Lubuk Basung propinsi Sumatera Barat.

1) Nagari Garagahan

Nagari Garagahan adalah salah satu nagari yang berada di daerah Lubuk Basung Sumatera Barat. Nagari Garagahan ini dipimpin oleh seorang kepala desa. Perangkat desa dari nagari Garagahan berjumlah 8 orang dengan rincian walinagari, sekretaris, kepala urusan pemerintahan, kepala urusan pembangunan, kepala urusan asset dan keuangan, kepala utusan kesra, bendahara nagari Garagahan, dan staff. Dimana latar belakang pendidikan mereka adalah D4/S1 (1 orang), DIII (3 orang) dan SLTA (4 orang). Tetapi dari latar belakang pendidikan mereka tersebut tidak ada yang berasal dari bidang ilmu akuntansi.

2) Nagari Lubuk Basung

Nagari Lubuk Basung terletak di Jalan Rasuna Said Lubuk Basung, Kecamatan Lubuk Basung, Kabupaten Agam, Propinsi Sumatera Barat. Nagari Lubuk Basung dikepalai oleh kepala desa dengan beberapa perangkat desa/nagari. Perangkat desa dari nagari Lubuk Basung berjumlah 4 orang dan semuanya berlatar pendidikan DIII, tetapi tidak ada yang bidang ilmunya akuntansi.

\section{Persoalan Yang Dihadapi}

Dengan keluarnya Undang Undang No. 6 Tahun 2014 yang membahas mengenai dana desa, dimana dalam UU tersebut dijelaskan bahwa desa/nagari nantinya pada tahun 2015 akan mendapatkan kucuran dana sebesar 10\% dari APBN. Kucuran dana tersebut tidak akan melewati perantara seperti sebelumnya yang harus melewati APBDesa dan bantuan pemerintah desa. Dana tersebut akan langsung sampai kepada desa/nagari. Tetapi jumlah 
nominal yang diberikan kepada masing-masing desa tergantung dari geografis desa, jumlah penduduk dan angka kematian. Bila kepala desa/ wali nagari maupun perangkatnya tidak menguasai akuntansi atau pengelolaan keuangan, sangat rawan terjadinya korupsi tingkat desa. Pada kedua mitra nagari ini sampai sekarang pembukuan yang dilaksanakan masih sangat sederhana. Mereka hanya mencatat transaksi yang terjadi setiap harinya secara manual dimana setiap kas yang masuk mereka catat sebagai pendapatan dan setiap kas yang keluar dicatat sebagai pengeluaran. Sehingga internal control terhadap pengelolaan keuangan nagari ini sangat lemah sekali.

Dapat disimpulkan dari kelompok mitra nagari ini persoalan yang mereka hadapi adalah sebagai berikut :

a. Sumberdaya manusia yang memahami pengelolaan keuangan belum ada pada mitra tersebut

b. Sumberdaya manusia yang memahami aplikasi yang sudah ada di pemerintah daerah belum ada.

c. Sarana dan prasarana berupa peralatan yang memadai untuk pengelolaan keuangan dan administrasi pada mitra belum tersedia.

Berdasakan latar belakang diatas memotivasi tim pengabdian untuk melakukan workshop pengelolaan keuangan desa/nagari serta membuat sebuah program pengelolaan keuangan dalam bentuk aplikasi excel yang nantinya akan bermanfaat bagi kedua mitra dalam pengelolaan keuangan dari nagari tersebut.

\section{Permasalahan Mitra}

Kedua desa/nagari ini memiliki banyak permasalahan, yaitu dari sumber daya manusia, penguasaan teknologi, dan pengelolaan keuangan desa/nagari. Masalah yang dihadapi oleh desa/nagari ini adalah :

Kepala desa/wali nagari maupun perangkatnya belum memiliki pengetahuan tentang akuntansi dan belum memiliki kemampuan dalam pengelolaan keuangan desa/nagari

\section{METODE PELAKSANAAN}

Metode pelaksanaan kegiatan ini untuk kedua kelompok mitra Nagari Garagahan dan Nagari Lubuk Basung adalah :

1. Melakukan workshop pengelolaan keuangan desa/nagari bagi kepala desa/wali nagari serta perangkat desa/nagari.

2. Membuatkan rancangan aplikasi pengelolaan keuangan desa/nagari dengan menggunakan microsoft excel versi 2010.

3. Pemberian peralatan berupa; laptop, printer, dan software aplikasi excel pengelolaan keuangan dalam bentuk excel laporan keuangan kepada masing-masing mitra kelompok desa/nagari.

4. Melakukan pengujian terhadap rancangan aplikasi excel yang dibuat bersama dengan kedua mitra desa/nagari.

5. Implementasi terhadap rancangan aplikasi excel yang dibuat bersama dengan kedua mitra desa/nagari.

6. Memberikan pelatihan, sosialisasi serta pendampingan kepada kedua mitra desa/nagari terhadap rancangan aplikasi excel yang dibuat sehingga kedua mitra tersebut dapat menyusun laporan keuangan.

7. Melakukan evaluasi terhadap rancangan aplikasi excel pengelolaan keuangan yang dibuat. Tujuannya agar diketahui sampai sejauh mana rancangan excel yang dibuat dapat berjalan dengan baik dan apabila ditemui kendala- kendala dilapangan maka 
langsung didiskusikan dengan pengelola dari kedua mitra kelompok desa/nagari ini.

Kegiatan dilaksanakan selama 8 (delapan) bulan terhitung kegiatan ini disetujui. Pertama sekali dilakukan survey lapangan kepada kedua kelompok mitra, sambil meminta data yang dibutuhkan untuk pembuatan rancangan aplikasi excel pengelolaan keuangan desa/nagari. Rancangan program dibuat di Politeknik Negeri Padang bersama dengan tim diperkirakan selama satu bulan. Setelah rancangan selesai dibuat maka tim langsung membuat aplikasi excel laporan keuangan selama tiga bulan. Kemudian baru dilakukan pengujian dan implementasi dari program excel laporan keuangan tersebut serta dilakukan sosialisasi dalam bentuk pelatihan dan pendampingan cara menyusun laporan keuangan dengan menggunakan program yang sudah dibuat. Disamping pelatihan bagaimana menggunakan program excel tersebut, kedua mitra desa/nagari juga mendapatkan workshop pengelolaan keuangan desa/nagari. Pelaksanaan workshop direncanakan dilakukan di tempat mitra tersebut karena masing- masing mitra mempunyai ruang rapat yang bisa dijadikan tempat pelatihan.

\section{HASIL DAN PEMBAHASAN}

Pelaksanaan kegiatan ini telah menyelesaikan beberapa tahap yaitu :

1. Melakukan workshop pengelolaan keuangan desa/nagari bagi kepala desa/wali nagari serta perangkat desa/nagari.

2. Membuatkan rancangan aplikasi pengelolaan keuangan desa/nagari dengan menggunakan microsoft excel versi 2010.

3. Pemberian peralatan berupa; laptop, printer, dan software aplikasi excel pengelolaan keuangan dalam bentuk excel laporan keuangan kepada masing-masing mitra kelompok desa/nagari.

4. Melakukan pengujian terhadap rancangan aplikasi excel yang dibuat bersama dengan kedua mitra desa/nagari.

5. Implementasi terhadap rancangan aplikasi excel yang dibuat bersama dengan kedua mitra desa/nagari.

6. Memberikan pelatihan, sosialisasi serta pendampingan kepada kedua mitra desa/nagari terhadap rancangan aplikasi excel yang dibuat sehingga kedua mitra tersebut dapat menyusun laporan keuangan.

7. Melakukan evaluasi terhadap rancangan aplikasi excel pengelolaan keuangan yang dibuat. Tujuannya agar diketahui sampai sejauh mana rancangan excel yang dibuat dapat berjalan dengan baik dan apabila ditemui kendala- kendala dilapangan maka langsung didiskusikan dengan pengelola dari kedua mitra kelompok desa/nagari ini.

\section{Partisipasi Mitra}

Mitra dalam hal ini adalah pengelola kelompok desa/nagari yaitu Nagari Garagahan dan Nagari Lubuk Basung. Partisipasi mereka dalam kegiatan ini adalah :

1) Mendukung pembuatan aplikasi excel pengelolan keuangan desa/nagari yang terkomputerisasi.

2) Memberikan informasi data dan informasi lainnya tentang persoalan yang mereka hadapi selama bertugas di desa/nagari tersebut.

3) Menunjuk Peserta. Peserta yang akan diikut sertakan dalam kegiatan ini adalah berdasarkan penunjukan atau rekomendasi dari kepala desa/wali nagari yang diberikan secara tertulis. Sedangkan peserta untuk mengikuti workshop pengelolaan 
keuangan desa adalah kepala desa/wali nagari serta perangkat desa/nagari.

4) Memberi motivasi, pengawasan dan pembinaan. Selama dalam kegiatan perancangan, pembuatan aplikasi excel pengelolaan keuangan desa/nagari, pengujian dan pelatihan, mitra diharapkan selalu memberikan motivasi, pengawasan dan pembinaan terhadap peserta.

\section{Analisis Kebutuhan Sistem Informasi Akuntansi Mitra}

Berdasarkan kunjungan dan wawancara yang telah dilaksanakan dengan mitra, dapat disimpulkan bahwa:

1. Mitra belum memiliki sistem informasi yang memadai untuk memenuhi kebutuhan akan pelaporan keuangan yang baik (sesuai standar akuntansi).

2. Mitra belum memiliki kompetensi yang cukup menganalisis transaksi keuangan dan menyusun laporan keuangan.

3. Mitra memerlukan pelatihan yang memadai mengenai analisis transaksi, menjurnal transaksi dan menyusun laporan keuangan yang sesuai dengan standar akuntansi.

4. Mitra memerlukan software aplikasi yaitu aplikasi pengelolaan keuangan desa/nagari yang dibuat dengan Microsoft Excel 2010 dengan tujuan agar mudah digunakan dan gampang untuk dilakukan perawatan (maintenance) di kemudian hari.

5. Mitra memerlukan pengetahuan dan keterampilan yang memadai untuk memperbaiki manajemen.

\section{Perancangan Aplikasi Program Pengelolaan Keuangan Mitra}

Perancangan program merupakan tahap penterjemahan dari kebutuhan sistem yang diperlukan untuk mempermudah pekerjaan pengguna aplikasi. Aplikasi akuntansi ini akan dirancang dengan menggunakan software Microsoft Excel 2010 . Tahap pertama dalam perancangan pengelolaan keuangan ini adalah menganalisis kebutuhan informasi pengguna. Kemudian tahap keduanya adalah merancang format apa saja yang akan dibutuhkan dalam menyusun laporan keuangan. Format yang akan dibuat untuk aplikasi ini adalah sebagai berikut :

\section{Pelaporan dan Pertanggungjawaban}

- Format Daftar Kode Rekening

- Format Neraca Saldo Awal

- Format Buku Kas Umum

- Format Buku Kas Pembantu Kegiatan

- Format Buku Kas Pembantu Pajak

- Format Buku Bank Nagari

- Format Jurnal Kegiatan Umum

- Format Jurnal Penutup

- Format Buku Besar

- Format Neraca Lajur

- Format Neraca Saldo Setelah Penutupan

- Format Surplus/Defisit

- Format Laporan Realiasasi Pelaksanaan Anggaran Pendapatan dan Belanja Nagari

- Format Laporan Perkembangan Pelaksana Kegiatan

- Format Laporan Pengaduan Masyarakat

- Format Laporan Penggunaan Bahan

- Format Laporan Kemajuan Pelaksanaan

- Format Laporan Masalah, Kendala dan Hambatan

\section{Daftar Realisasi}


- Format Surat Permintaan Pembayaran

- Format Pernyataan Tanggung Jawab Belanja

- Format Daftar Realisasi Dana Swadaya

- Format Daftar Realisasi Swadaya Bahan/Barang

- Format Daftar Realisasi Tenaga Sukarela

- Format Daftar Realisasi Biaya Kegiatan

- Format Daftar Hadir dan Insentif

- Format Daftar Kebutuhan Material

- Format Daftar Calon Tenaga Kerja

\section{Rencana Anggaran}

- Format Rencana Anggaran Biaya

- Format Rencana Penggunaan Dana

- Format Rencana Kegiatan

- Format Jadwal Pelaksanaan Pekerjaan

\section{Lain-Lain}

- Format Kwitansi

- Format Pendataan Kebutuhan Tenaga Kerja

- Format Ceklis Dokumen Administrasi

- Format Hasil Pemeriksaan Kegiatan

Untuk bagian Pelaporan dan Pertanggungjawaban, terdiri dari :

Format Daftar Kode Rekening

Format iniberisitentang daftarkode rekening dan nama rekeningyang terdapat padakedua nagari.

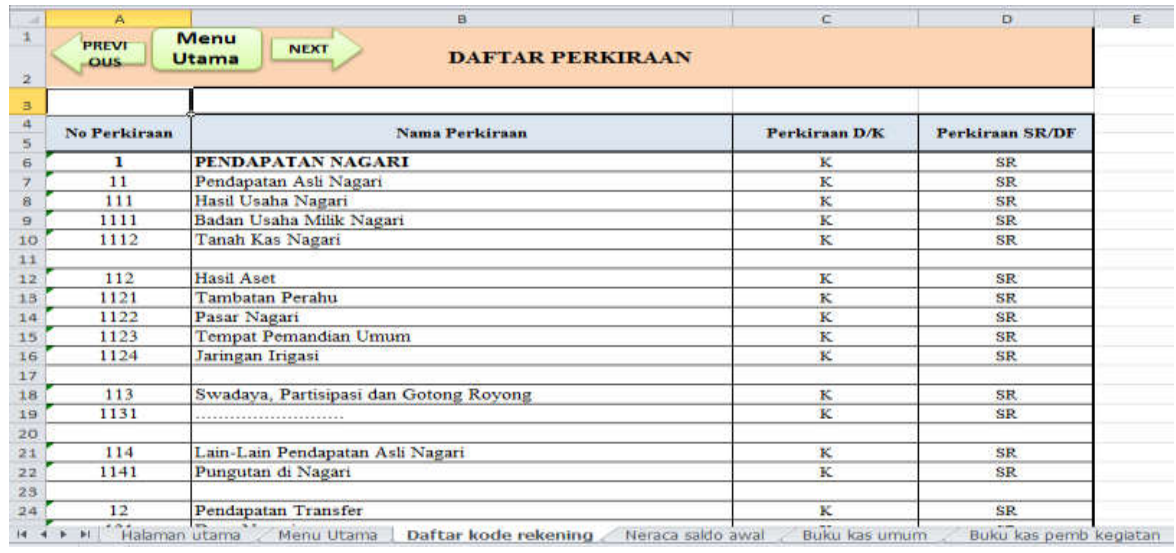

Gambar 3.1. Format Daftar Kode Rekening

Format Neraca Saldo Awal

Format iniberisitentang saldo awal yang terdapat padakedua nagari. 


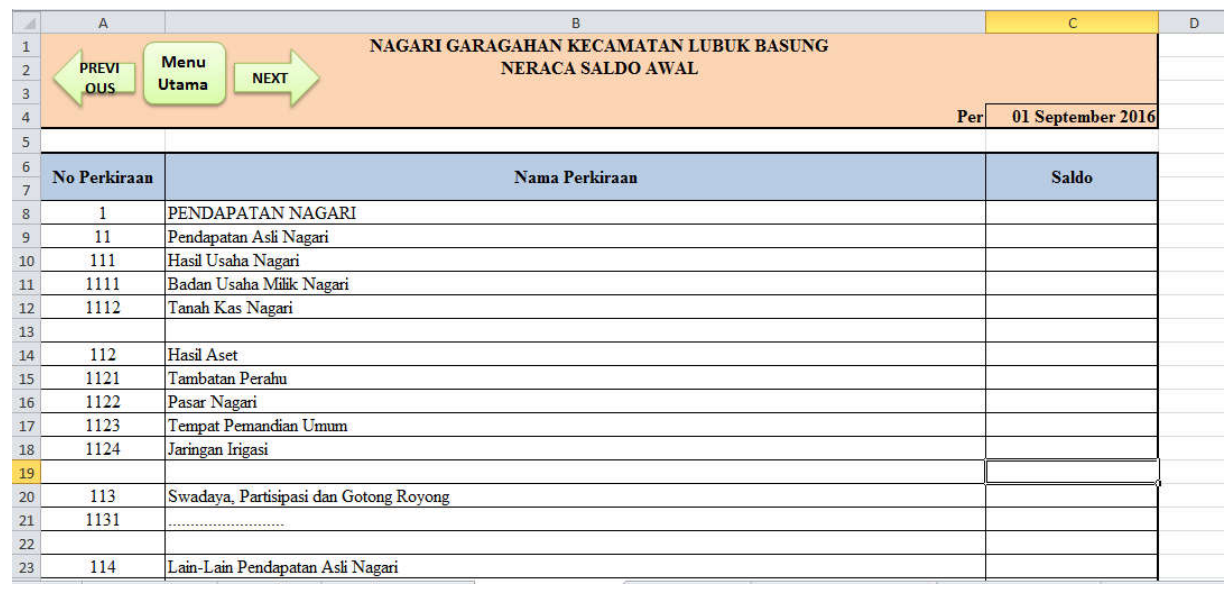

Gambar 3.2. Format Neraca Saldo Awal

Format Buku Kas Umum

Format ini mencatat semua transaksi yang berkaitan dengan Kas Umum yangterdapat padakedua nagari.

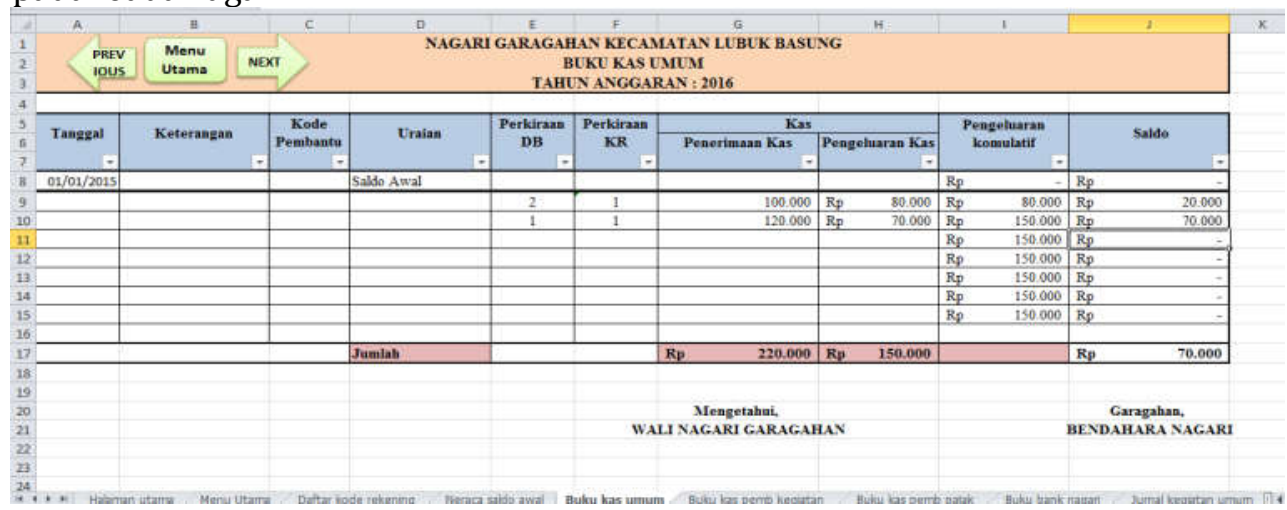

Gambar 3.3. Format Buku Kas Umum

Format Buku Kas Pembantu Kegiatan

Format ini mencatat semua transaksi yang berkaitan dengan Kas Pembantu Kegiatan yangterdapat padakedua nagari.

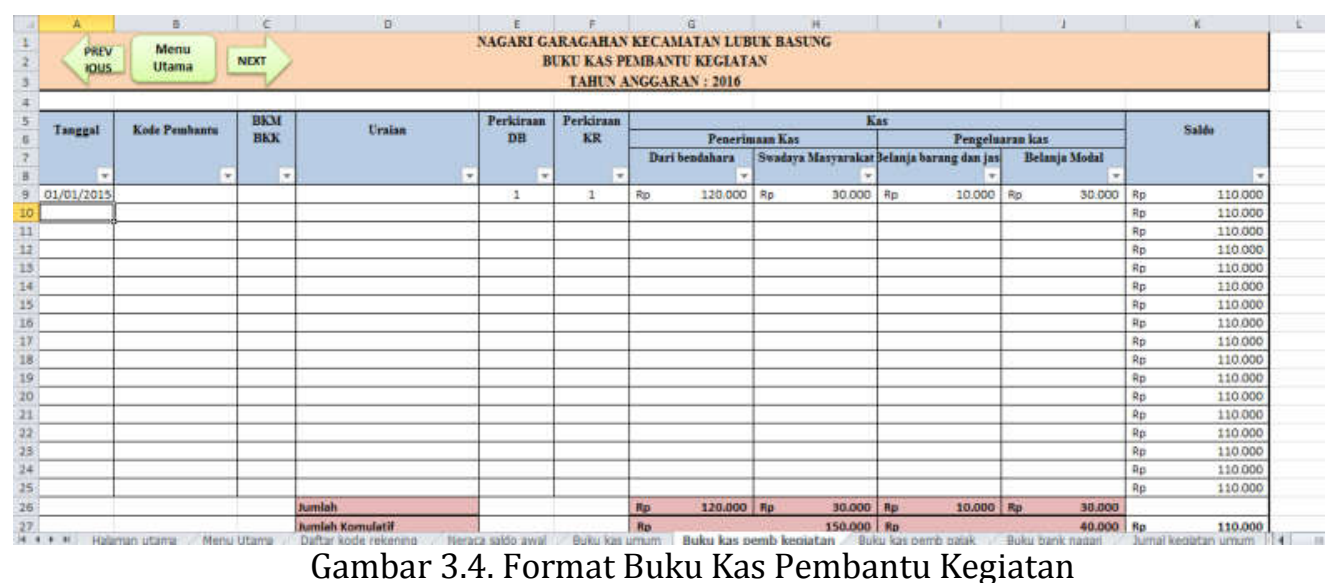

Format Buku Kas Pembantu Pajak

Format ini mencatat semua transaksi yang berkaitan dengan Kas Pajak yangterdapat padakedua nagari. 


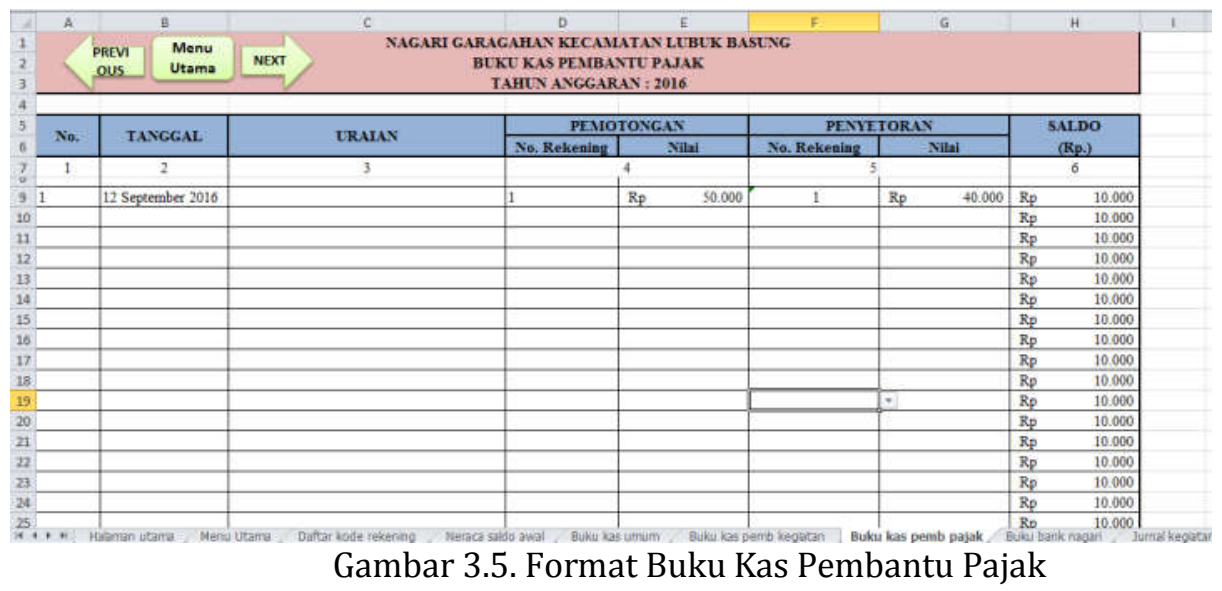

Format Buku Bank Nagari

Format ini mencatat semua transaksi yang berkaitan dengan Bank Nagari baik penerimaan maupun pengeluaran yangterdapat padakedua nagari.

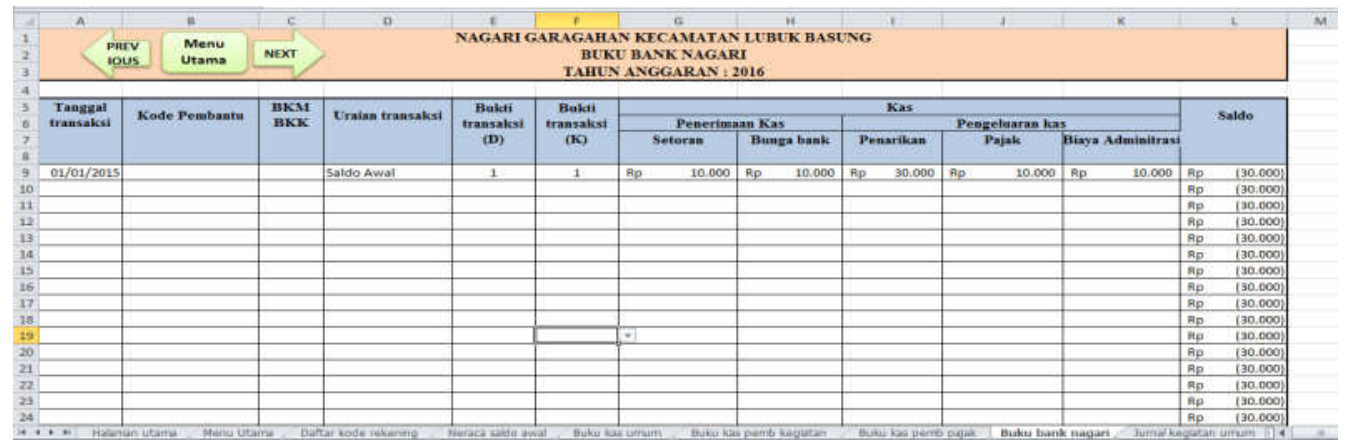

Gambar 3.6. Format Buku Bank Nagari

Format Jurnal Kegiatan Umum

Format ini mencatat semua transaksi yang berkaitan dengan kegiatan umum yangterdapat padakedua nagari.

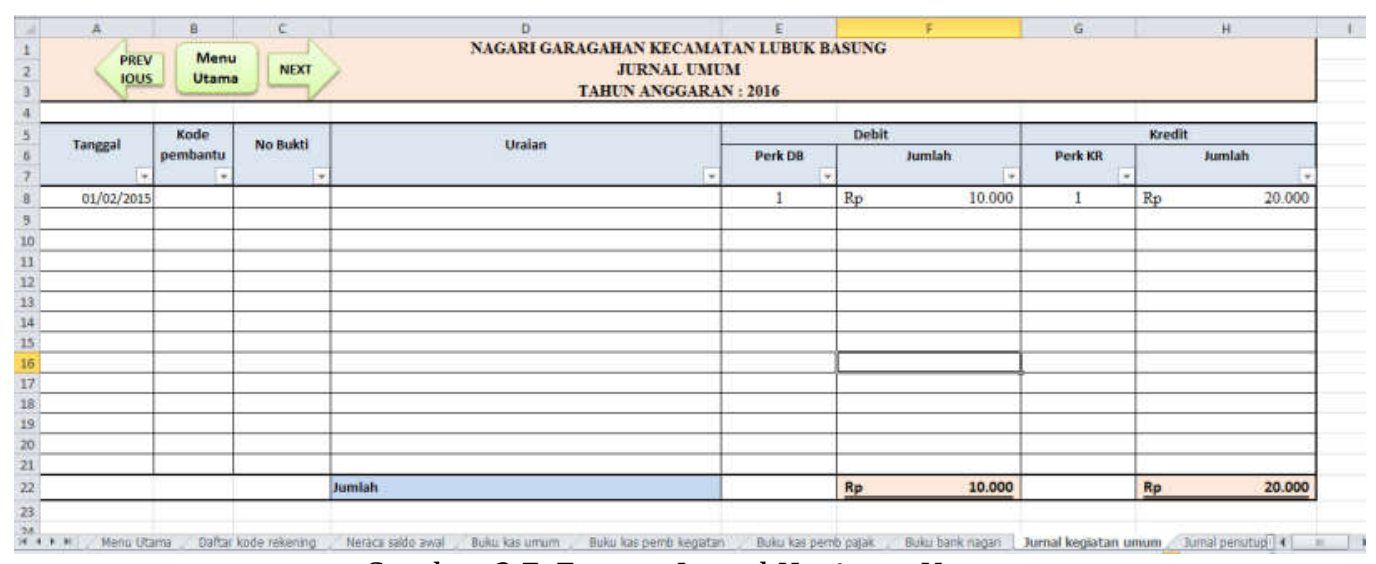

Gambar 3.7. Format Jurnal Kegiatan Umum

Format Jurnal Penutup

Format ini mencatat semua transaksi yang berkaitan dengan jurnal penutup 
yangterdapat padakedua nagari.

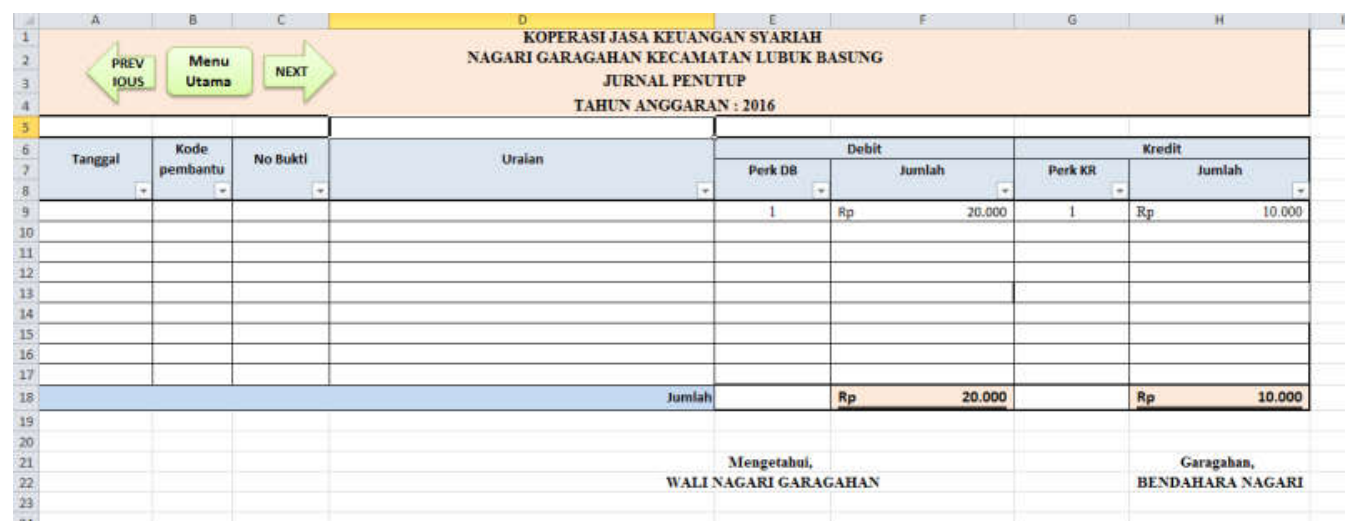

Gambar 3.8. Format Jurnal Penutup

Format Buku Besar

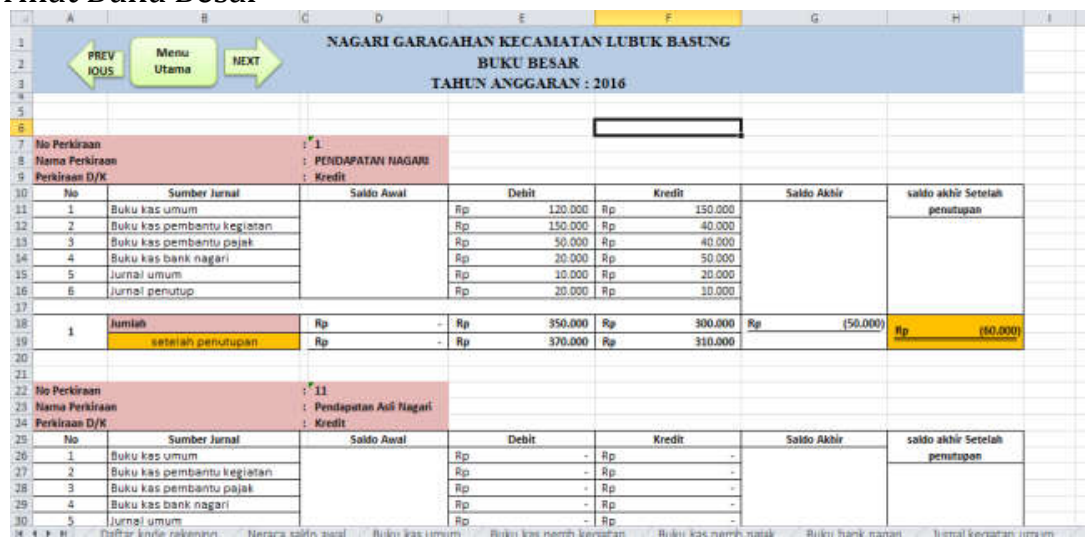

Gambar 3.9. Format Buku Besar

Format Neraca Lajur

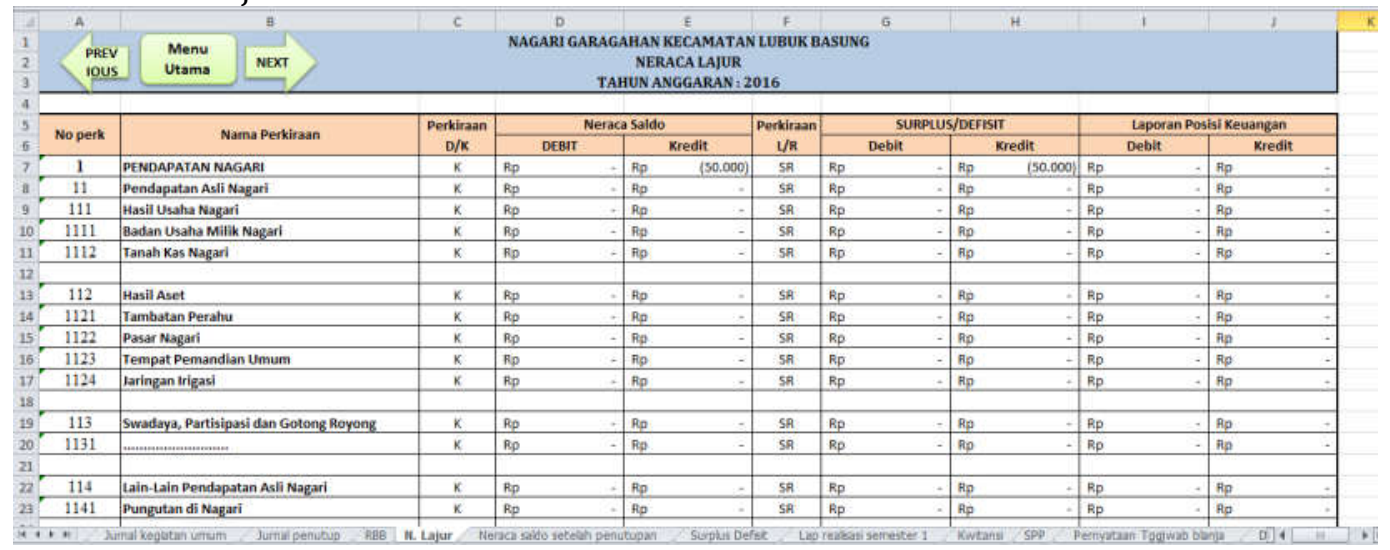

Gambar 3.10. Format Neraca Lajur

Format Neraca Saldo Setelah Penutupan 


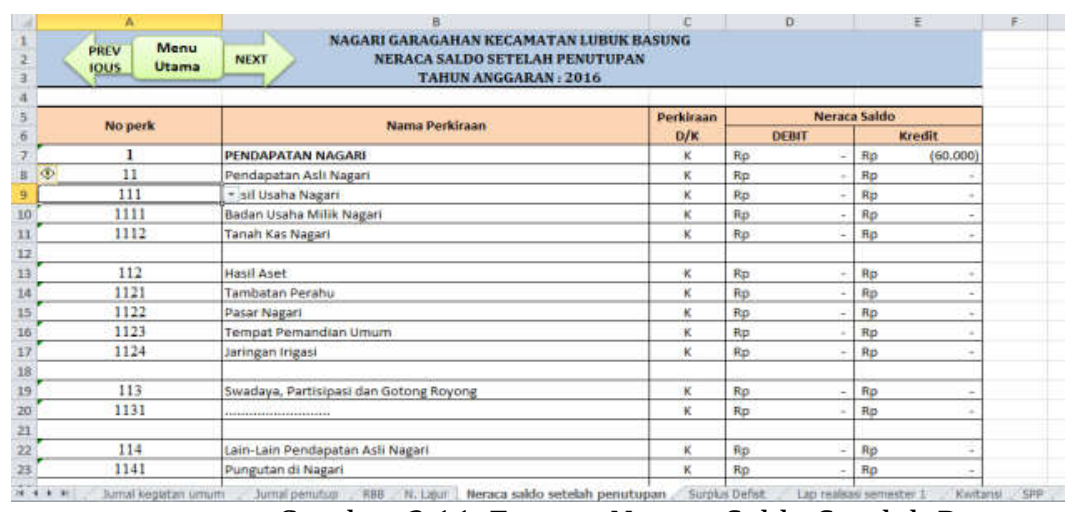

Gambar 3.11. Format Neraca Saldo Setelah Penutupan

Format Surplus/Defisit

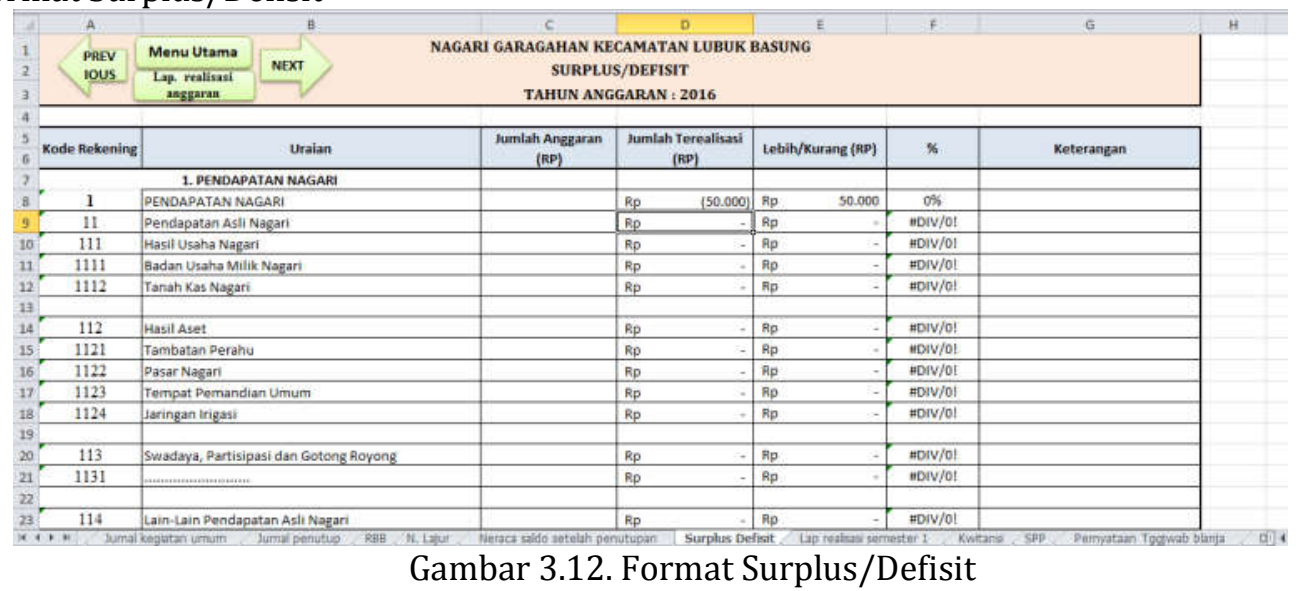

Format Laporan Realiasasi Pelaksanaan Anggaran Pendapatan dan Belanja Nagari

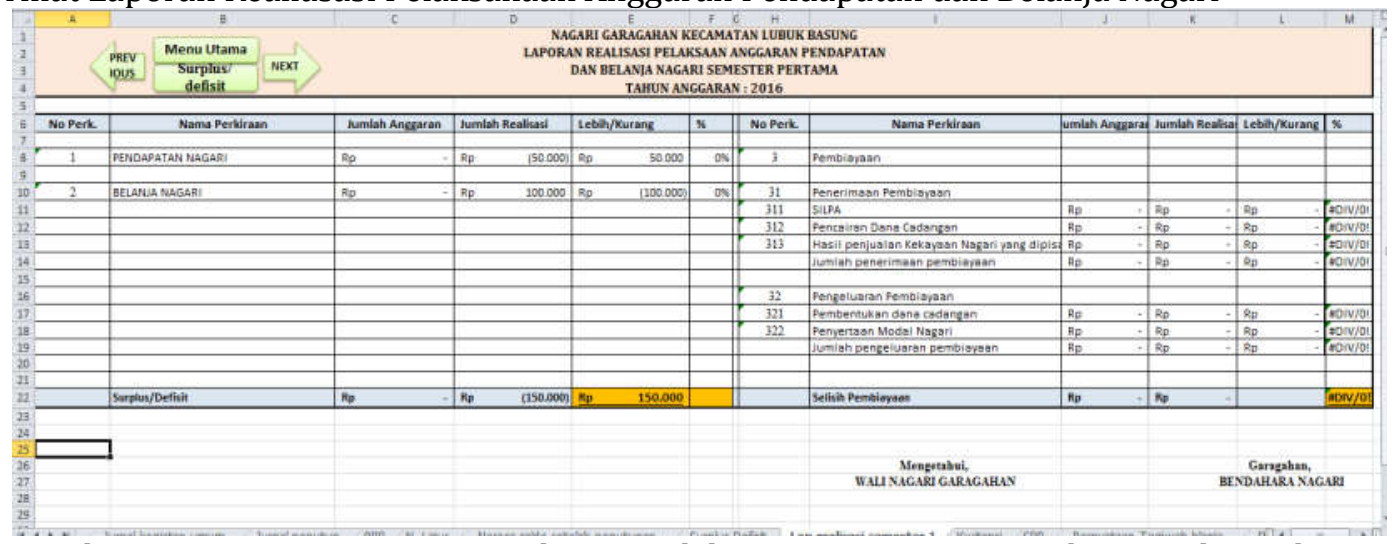

Gambar 3.13. Format Laporan Realiasasi Pelaksanaan Anggaran Pendapatan dan Belanja Nagari

Format Laporan Perkembangan Pelaksana Kegiatan 


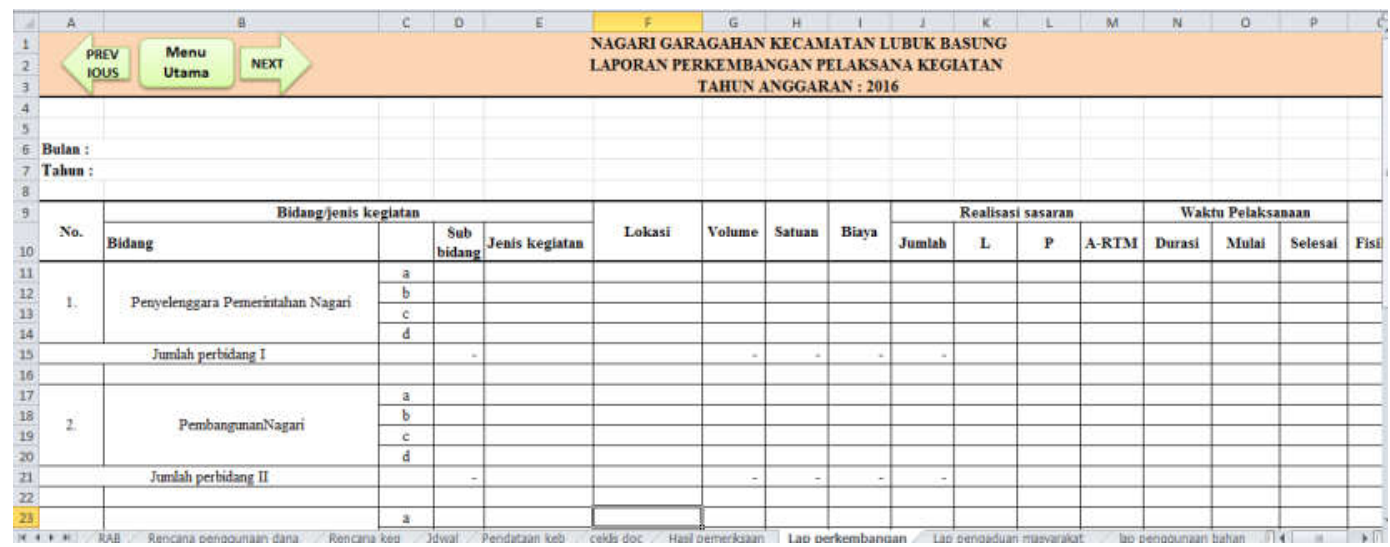

Gambar 3.14. Format Laporan Perkembangan Pelaksana Kegiatan

Format Laporan Pengaduan Masyarakat

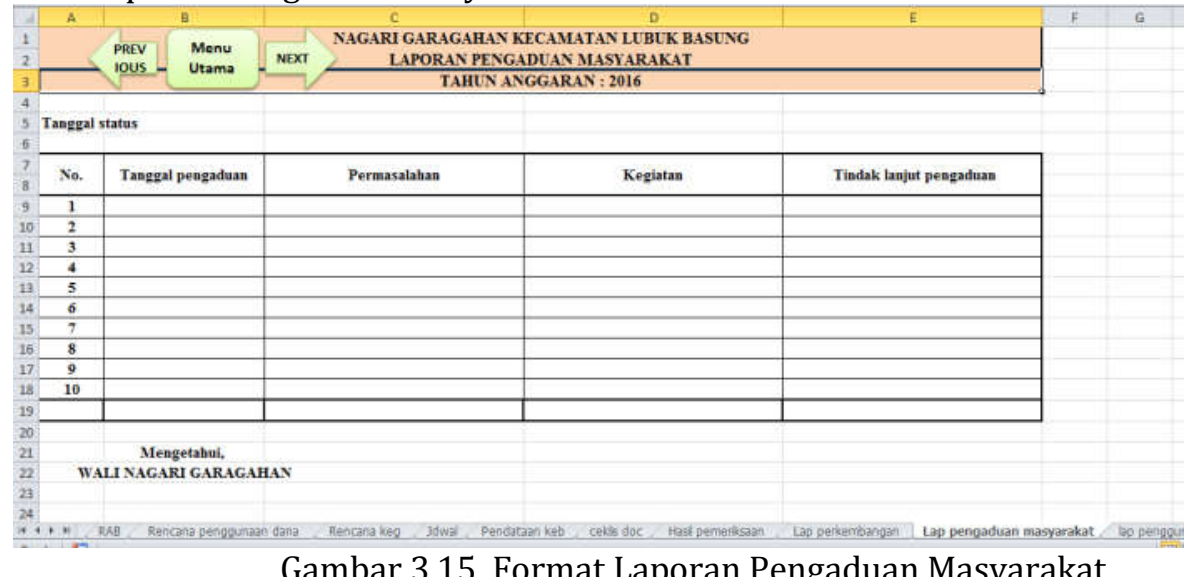

Gambar 3.15. Format Laporan Pengaduan Masyarakat

Format Laporan Penggunaan Bahan

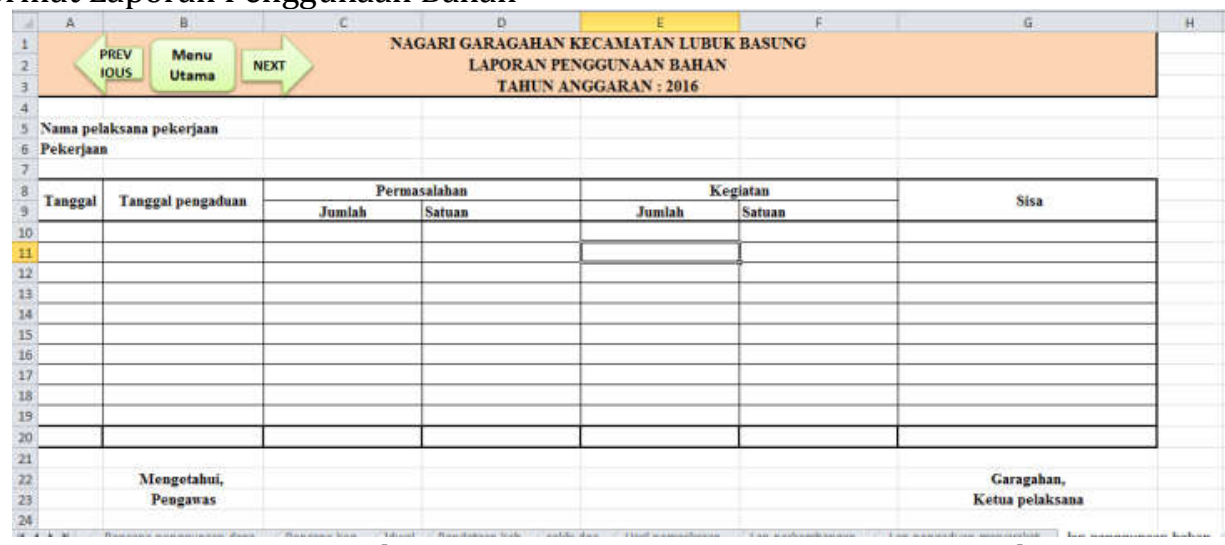

Gambar 3.16. Format Laporan Penggunaan Bahan

Format Laporan Kemajuan Pelaksanaan 


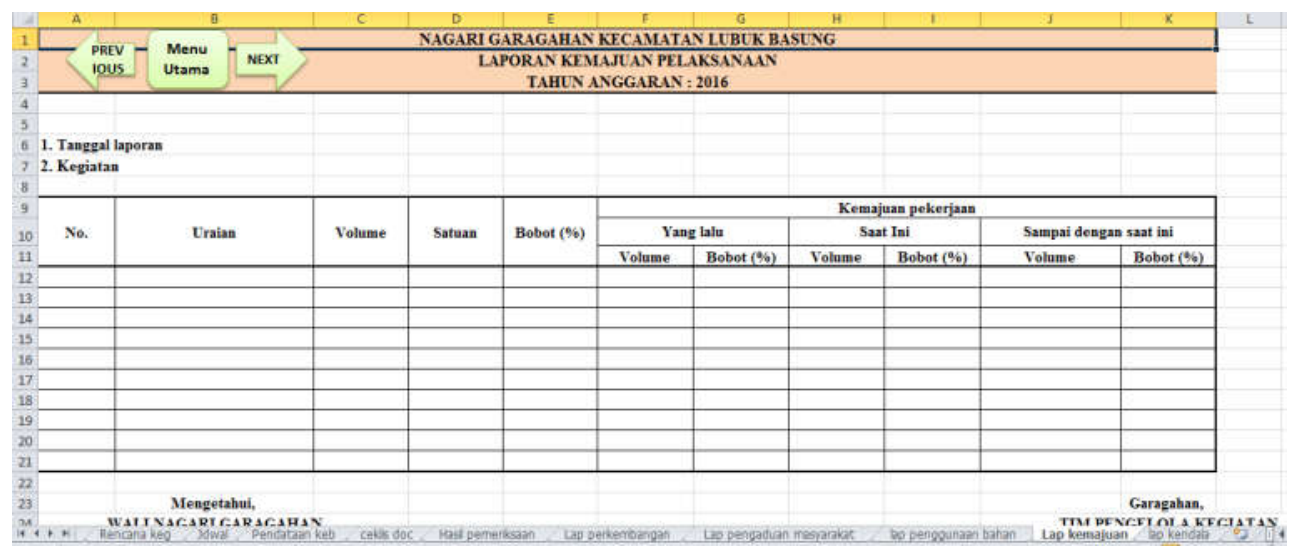

Gambar 3.17. Format Laporan Kemajuan Pelaksanaan

Format Laporan Masalah, Kendala dan Hambatan

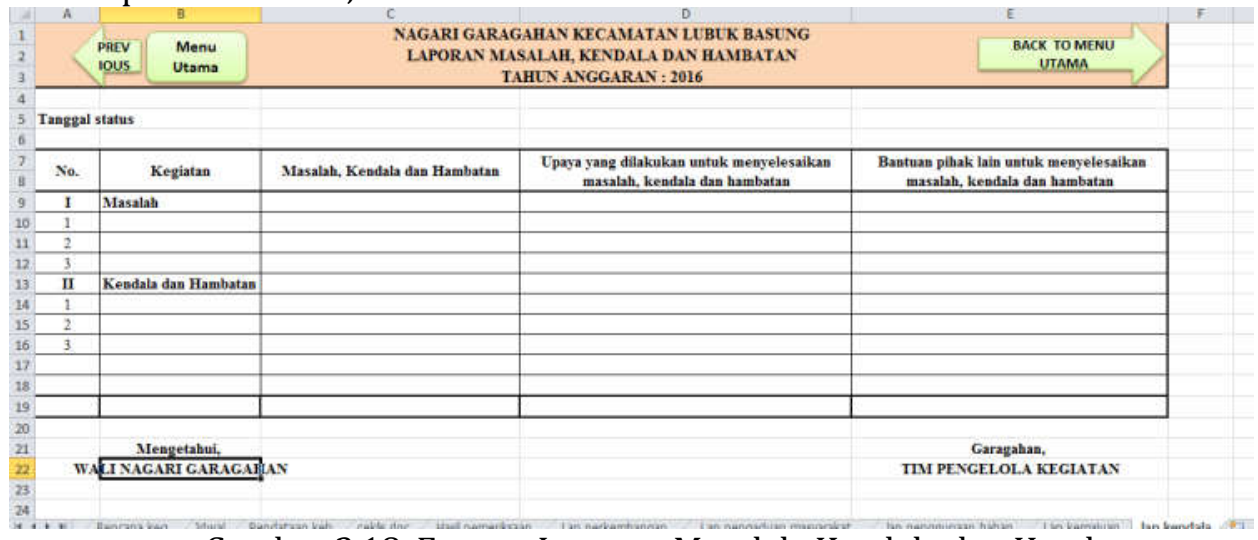

Gambar 3.18. Format Laporan Masalah, Kendala dan Hambatan

Untuk bagian Daftar Realisasi terdiri dari :

Format Surat Permintaan Pembayaran

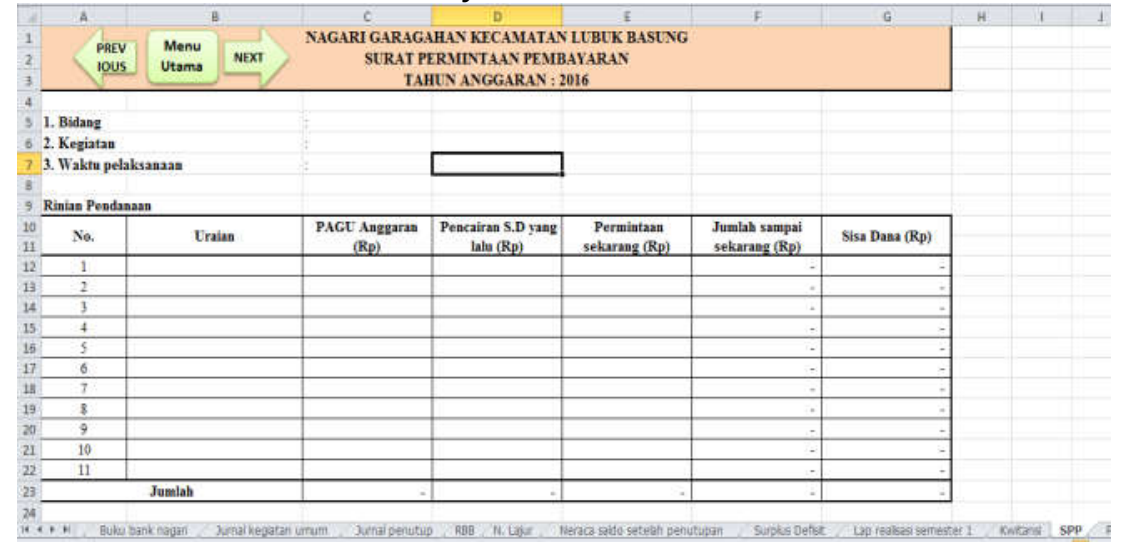

Gambar 3.19. Format Surat Permintaan Pembayaran

Format Pernyataan Tanggung Jawab Belanja 


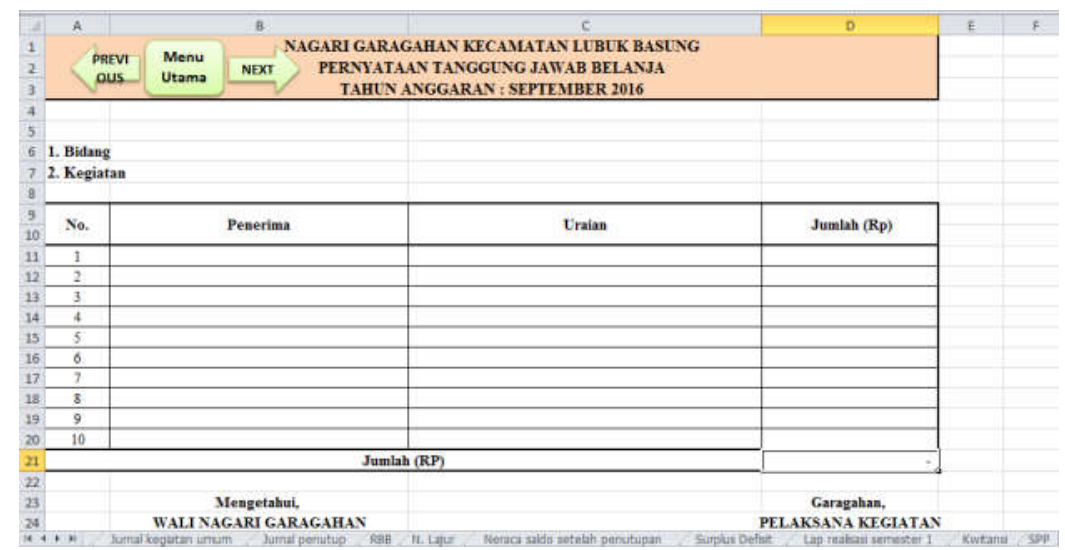

Gambar 3.20. Format Pernyataan Tanggung Jawab Belanja

Format Daftar Realisasi Dana Swadaya

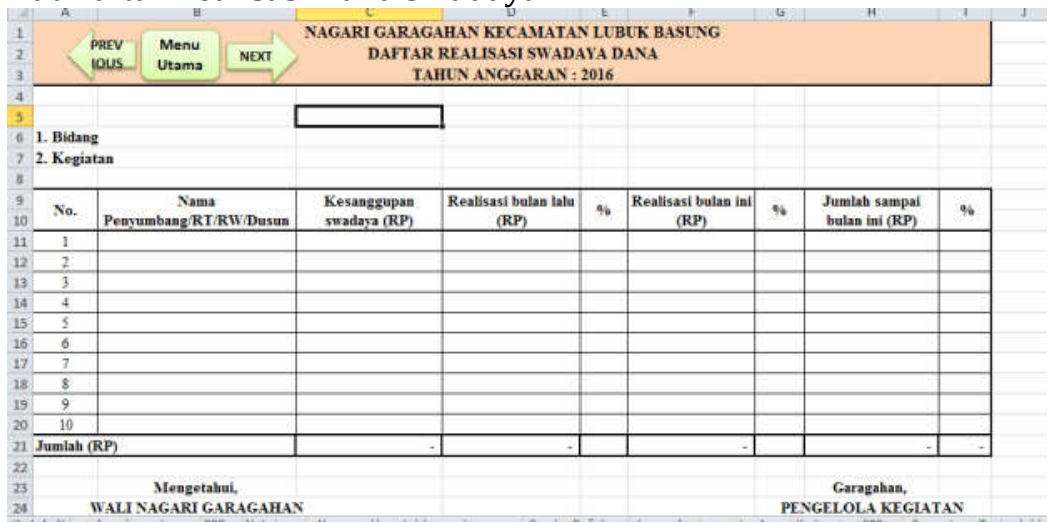

Gambar 3.21. Format Daftar Realisasi Dana Swadaya

Format Daftar Realisasi Swadaya Bahan/Barang

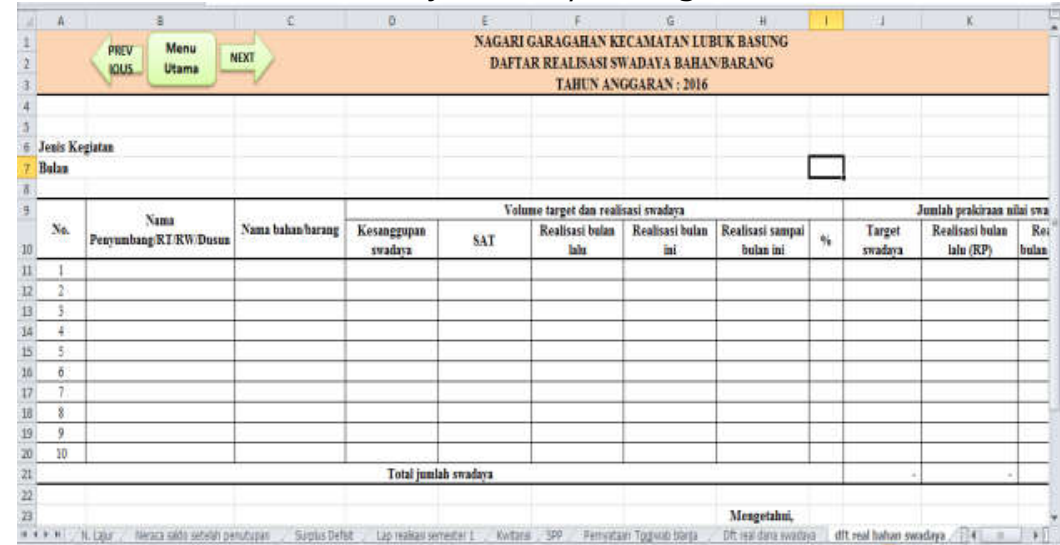

Gambar 3.22. Format Daftar Realisasi Swadaya Bahan/Barang

Format Daftar Realisasi Tenaga Sukarela 


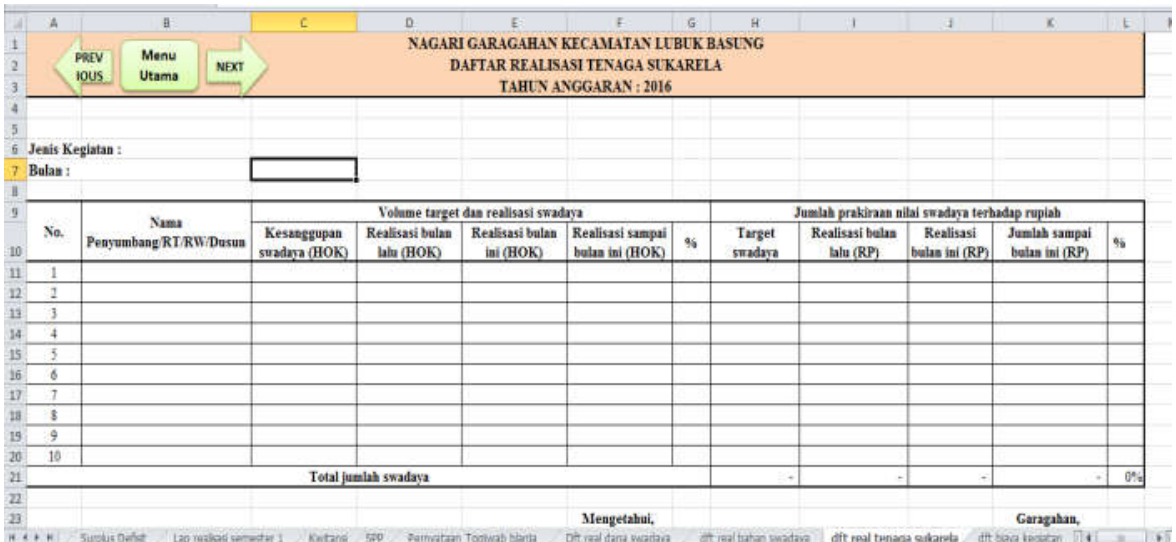

Gambar 3.23. Format Daftar Realisasi Tenaga Sukarela

Format Daftar Realisasi Biaya Kegiatan

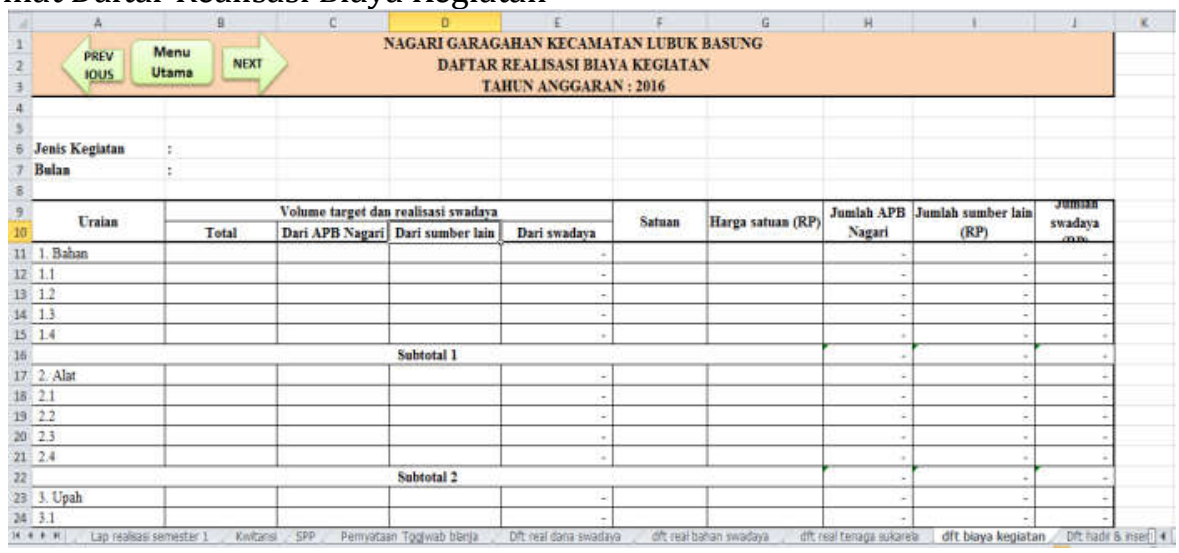

Gambar 3.24. Format Daftar Realisasi Biaya Kegiatan

Format Daftar Hadir dan Insentif

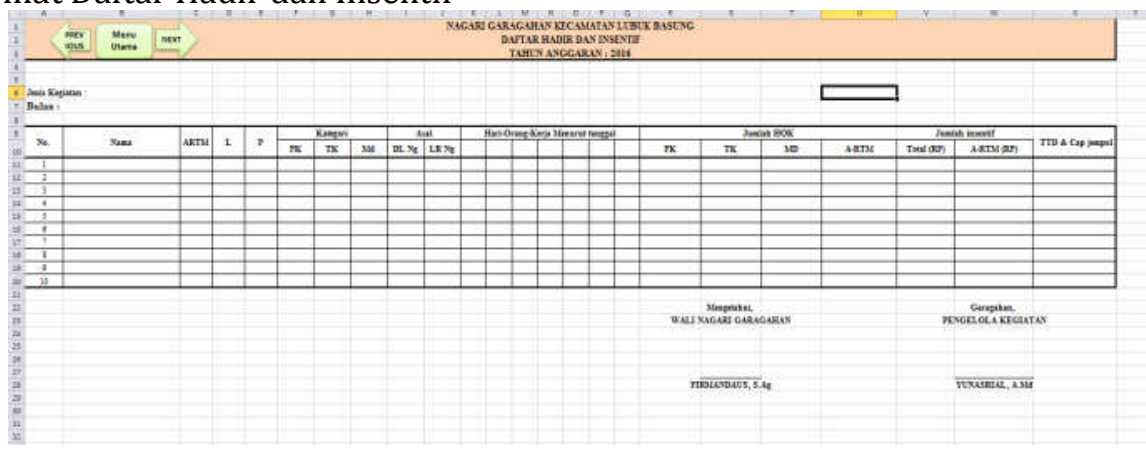

Gambar 3.25. Format Daftar Hadir dan Insentif

Format Daftar Kebutuhan Material 


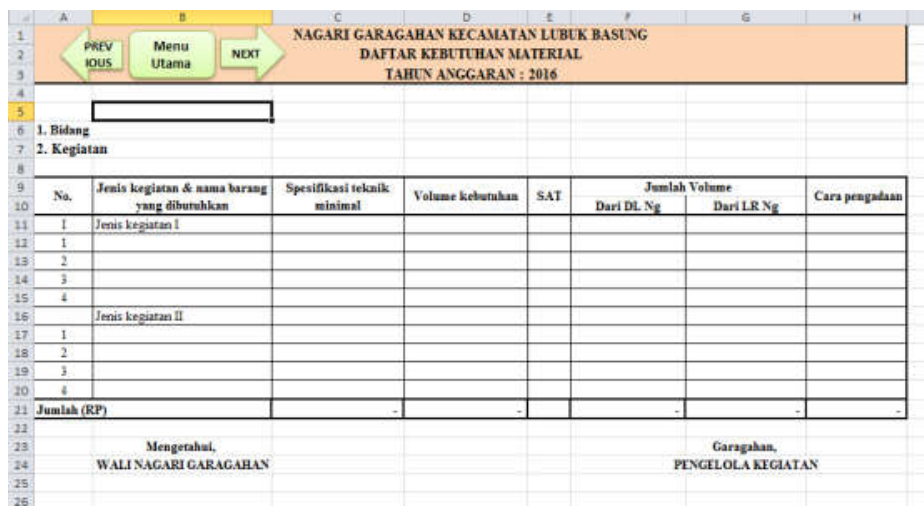

Gambar 3.26. Format Daftar Kebutuhan Material

Format Daftar Calon Tenaga Kerja

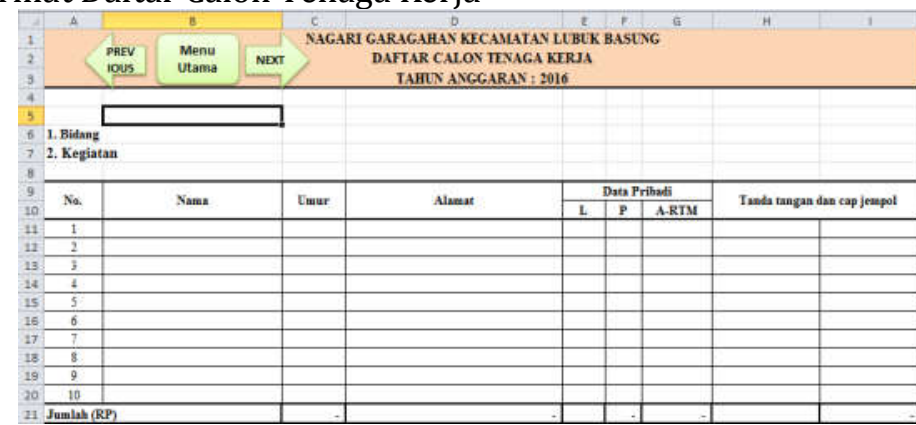

Gambar 3.27. Format Daftar Calon Tenaga Kerja

Untuk Rencana Anggaran terdiri dari :

Format Rencana Anggaran Biaya

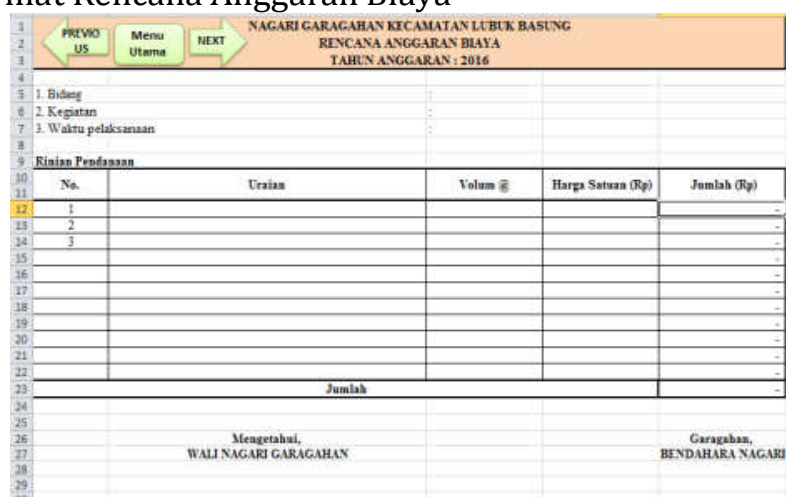

Gambar 3.28. Format Rencana Anggaran Biaya

Format Rencana Penggunaan Dana 


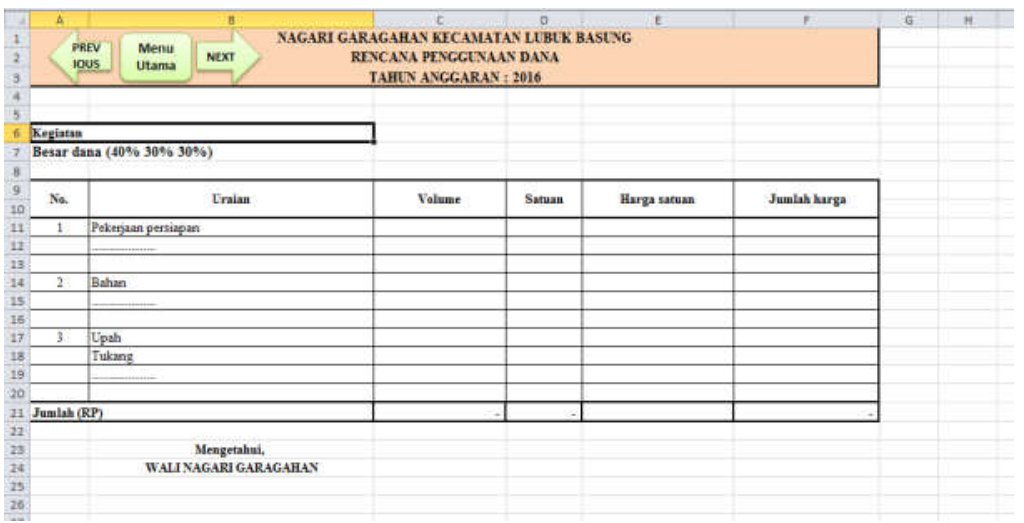

Gambar 3.29. Format Rencana Penggunaan Dana

Format Rencana Kegiatan

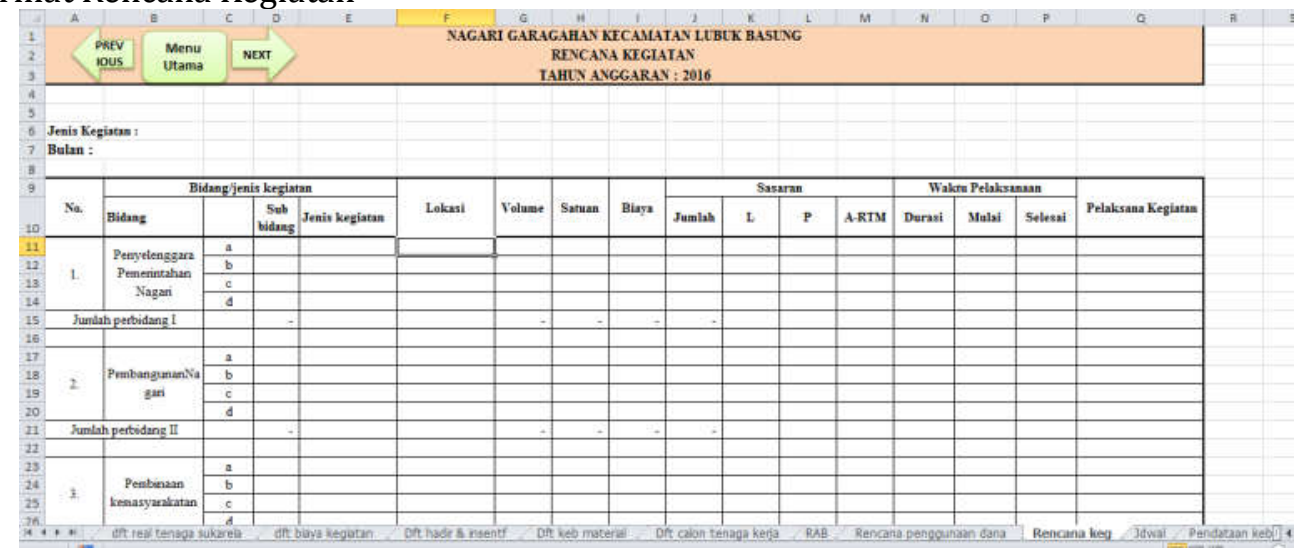

Gambar 3.30. Format Rencana Kegiatan

Format Jadwal Pelaksanaan Pekerjaan

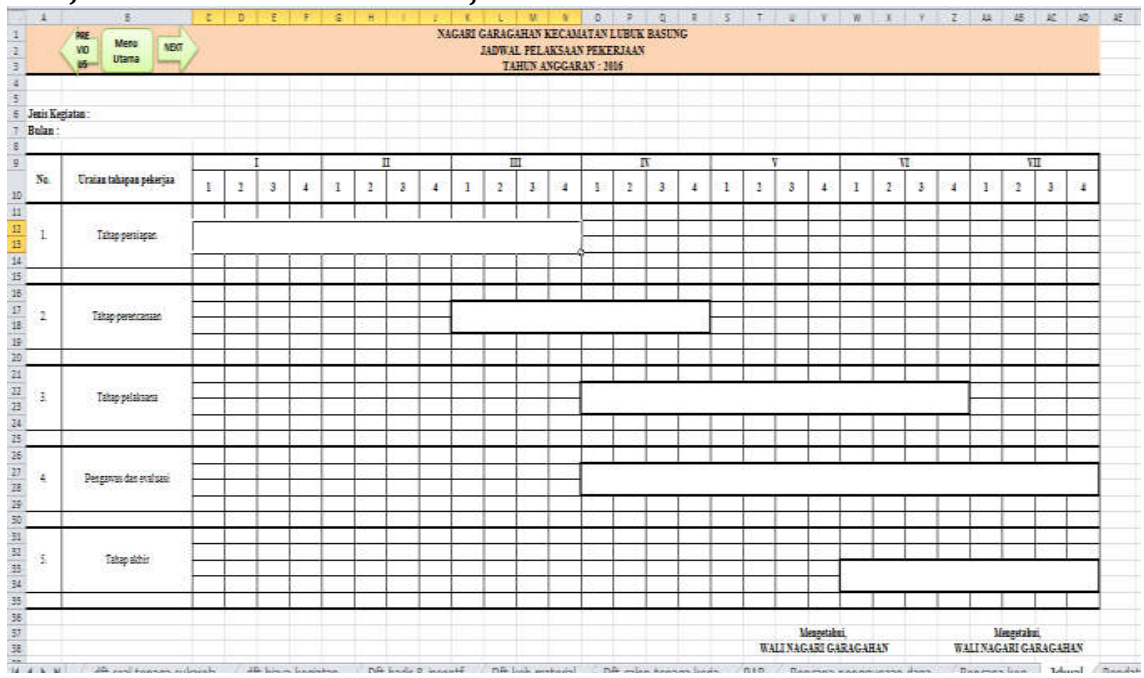

Gambar 3.31. Format Jadwal Pelaksanaan Kegiatan

\section{Untuk Lain-Lain terdiri dari :}

Format Kwitansi 


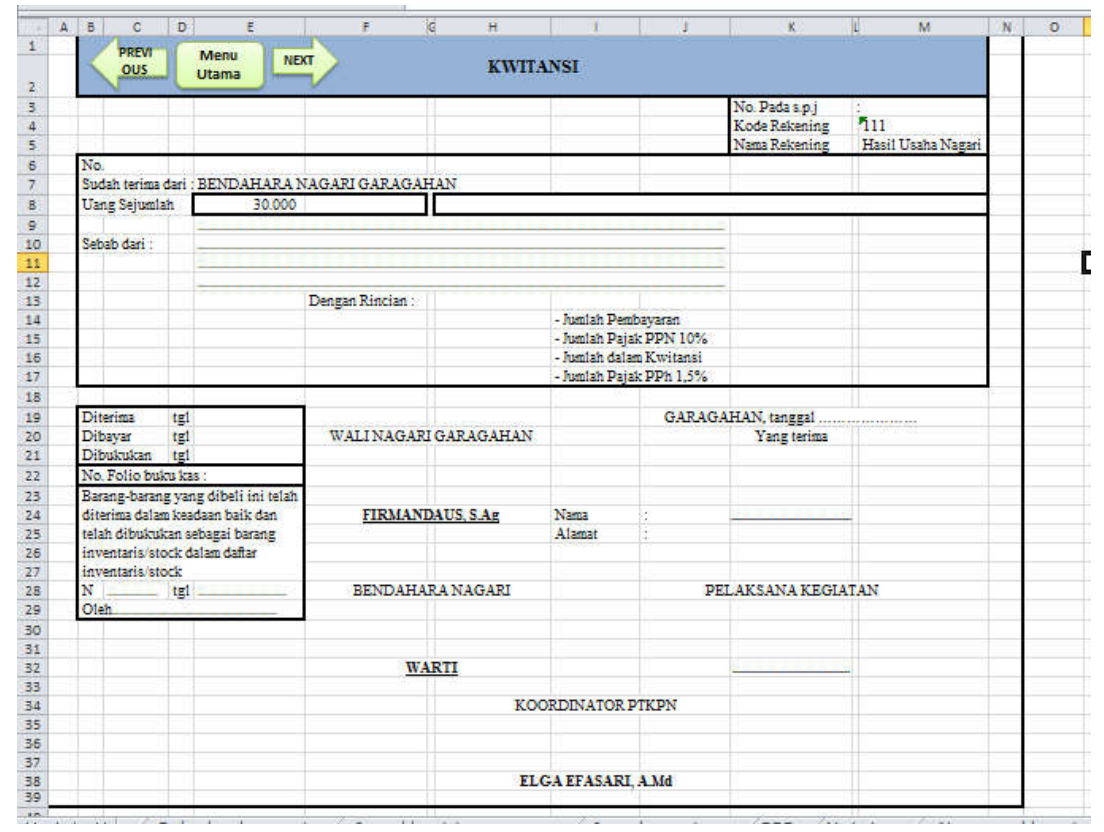

Gambar 3.32. Format Kwitansi

Format Pendataan Kebutuhan Tenaga Kerja

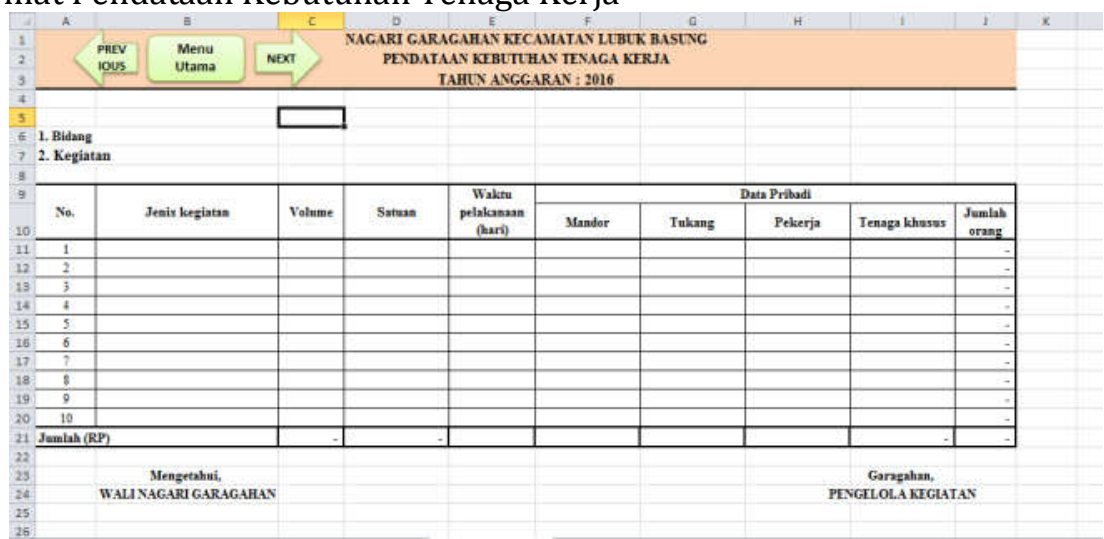

Gambar 3.33. Format Pendataan Kebutuhan Tenaga Kerja

Format Ceklis Dokumen Administrasi

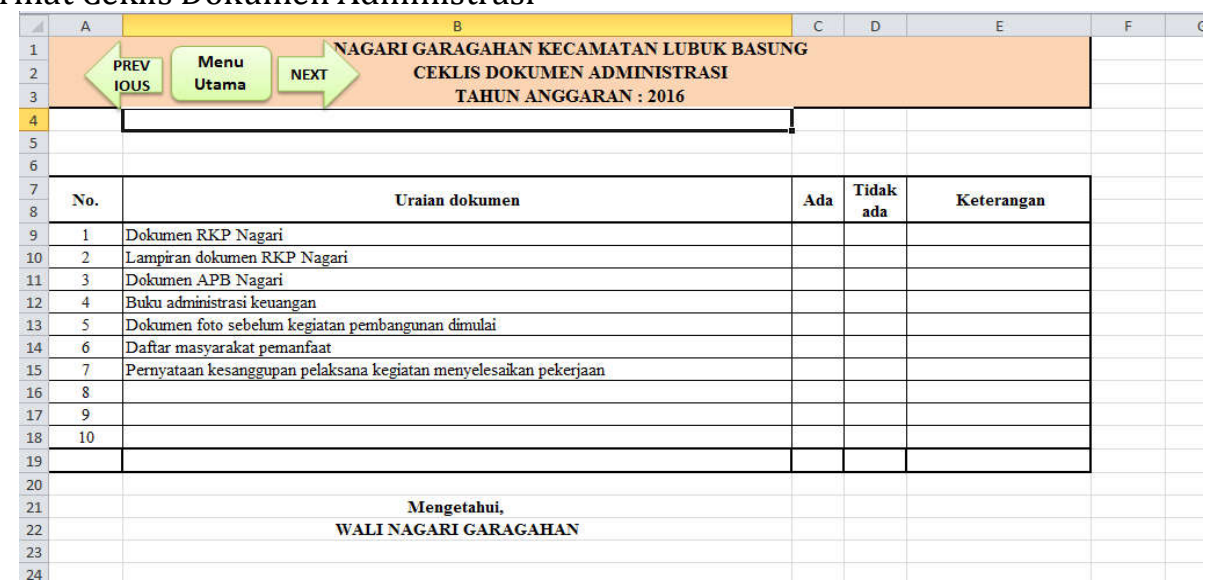

Gambar 3.34. Format Ceklis Dokumen Administrasi 
Format Hasil Pemeriksaan Kegiatan

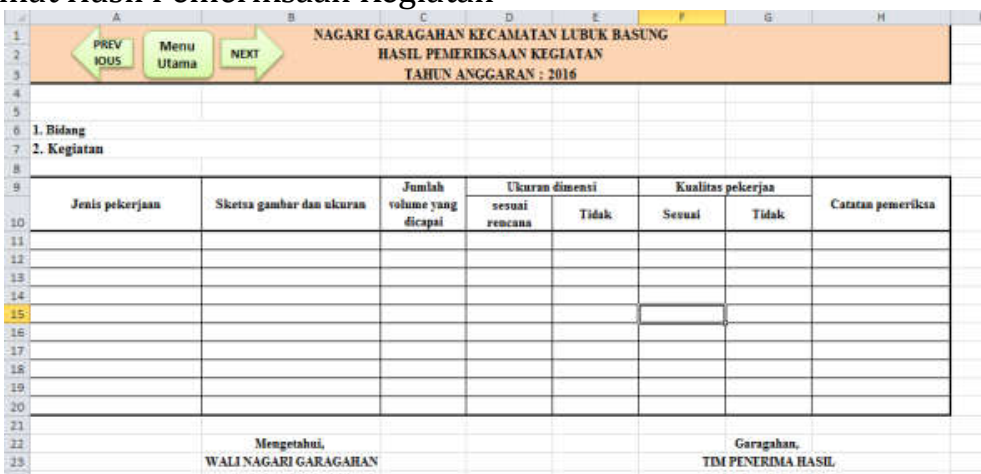

Gambar 3.35. Format Hasil Pemeriksaan Kegiatan

\section{Luaran yang Dihasilkan}

Luaran yang dihasilkan dari kegiatan ini adalah :

1. Terlatihnya kepala desa/wali nagari beserta perangkat desa/nagari dalam melaksanakan pengelolaan keuangan desa/nagari.

2. Adanya program aplikasi excel tentang pengelolaan keuangan pada kedua kelompok mitra desa/nagari. Hal ini dibuktikan dengan diberikannya software aplikasi pengelolaan keuangan nagari dengan menggunakan microsoft excel kepada kedua mitra.

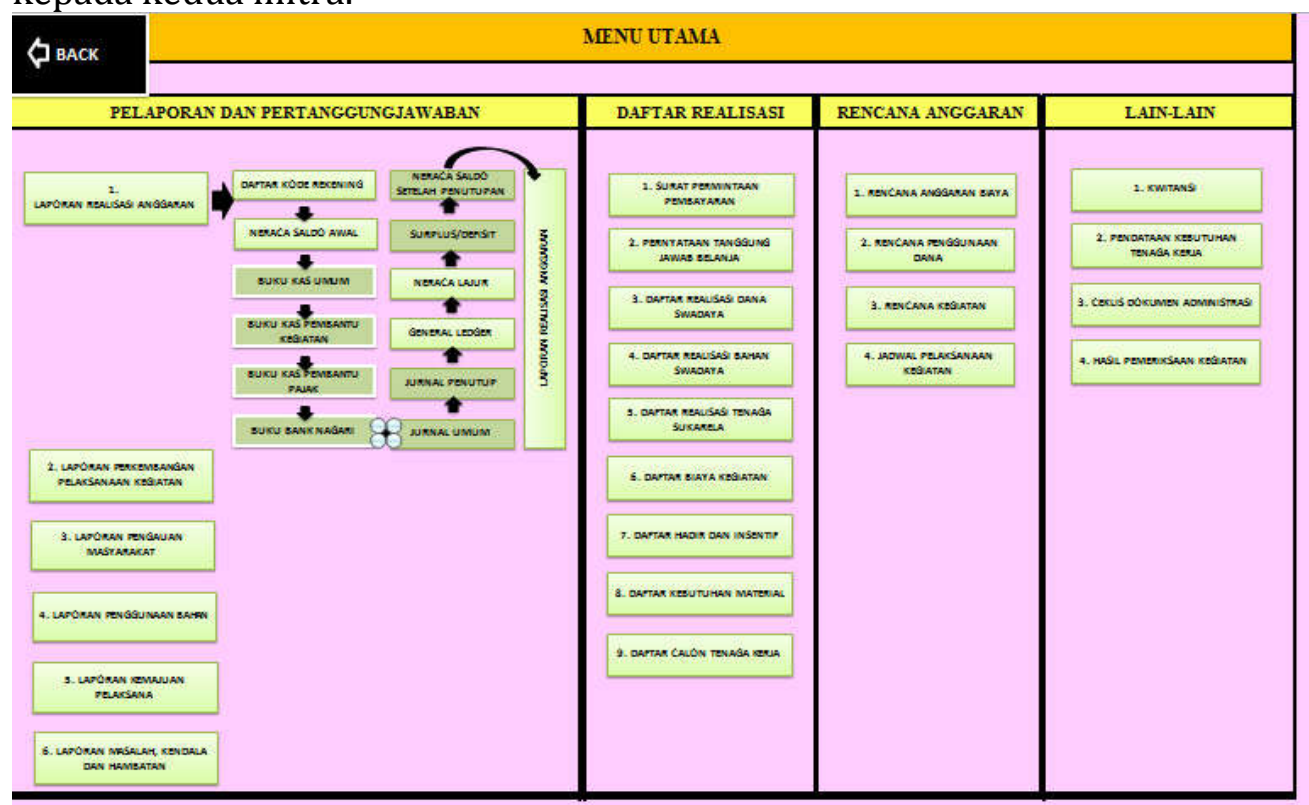

Gambar 3.36. Menu Utama Aplikasi Excel Pengelolaan Keuangan Desa/Nagari

3. Adanya kepala desa/wali nagari beserta perangkat desa/nagari dari kelompok mitra ini yang memiliki kemampuan dalam mengoperasikan excel pengelolaan keuangan yang sudah dibuat.

4. Adanya kepala desa/wali nagari beserta perangkat desa/nagari dari kelompok mitra ini yang memiliki kemampuan dalam menganalisa dan menginput transaksi keuangan pada aplikasi excel yang dibuat. Hal ini dibuktikan dengan diberikannya "Modul Panduan Pengelolaan Keuangan Desa/Nagari". 


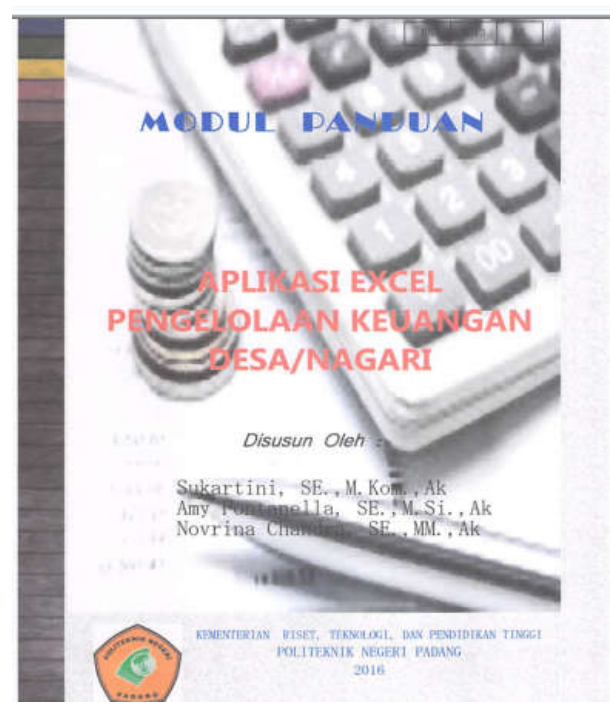

Gambar 3.37. Modul Panduan Aplikasi Pengelolaan Keuangan Desa/Nagari Didalam modul panduan ini kita menjelaskan tentang bagaimana cara mengoperasikan rancangan aplikasi yang dibuat serta panduan dalam menginput transaksi keuangan sehingga menghasilkan laporan keuangan desa/nagari.

5. Kepala desa/wali nagari beserta perangkat desa/nagari bisa mendapatkan informasi setiap saat dengan mengakses aplikasi excel pengelolan keuangan tersebut.

\section{KESIMPULAN}

Dari hasil observasi yang telah dilakukan kepada kedua mitra Nagari Garagahan dan Nagari Lubuk Basung baik lewat pengamatan dan wawancara dapat diidentifikasi masalah yang muncul. Berdasarkan kunjungan dan wawancara yang telah dilaksanakan dengan mitra tersebut, dapat disimpulkan bahwa:

1. Mitra belum memiliki sistem informasi yang memadai untuk memenuhi kebutuhan akan pelaporan keuangan yang baik (sesuai standar akuntansi).

2. Mitra belum memiliki kompetensi yang cukup menganalisis transaksi keuangan dan menyusun laporan keuangan.

3. Mitra memerlukan pelatihan yang memadai mengenai analisis transaksi, menjurnal transaksi dan menyusun laporan keuangan yang sesuai dengan standar akuntansi.

4. Mitra memerlukan software aplikasi yaitu aplikasi program pengelolaan keuangan desa/nagari yang dibuat dengan Microsoft Excel 2010 dengan tujuan agar mudah digunakan dan gampang untuk dilakukan perawatan (maintenance) di kemudian hari.

5. Mitra memerlukan pengetahuan dan keterampilan yang memadai untuk memperbaiki laporan pertanggungjawaban serta laporan keuangan.

\section{REFERENSI}

[1] Arifin, Johar, Komputer Akuntansi dengan Microsoft Excel, Elexmedia Komputindo, Jakarta, Tahun 2006 
[2] DP2M Ristekdikti (2016). Panduan Pelaksanaan Penelitian dan PPM Edisi-X 2016, Jakarta : Direktorat Riset dan Pengabdian Kepada Masyarakat, Direktorat Jenderal Penguatan Riset dan Pengembangan, Kementerian Riset, Teknologi dan Pendidikan Tinggi.

[3] Kusrianto, Adi, Mengupas Tuntas Formula dan Fungsi Microsoft Excel, Elexmedia Komputindo, Jakarta, Tahun 2000

[4] Soemarso SR, Akuntansi Suatu Pengantar, Salemba , Jakarta, 2004

[5] Syarifuddin, Program Aplikasi Akuntansi dengan Microsoft Excel, Qowamedia Utama, Solo, Tahun 2004

[6] Tanjung, Abdul Hafiz, Akuntansi Pemerintahan Daerah Berbasis Akrual : Pendekatan Teknis Sesuai PP No. 71/2010, Bandung, Alfabeta, Tahun 2012 